\title{
ANALISIS, PERANCANGAN \& IMPLEMENTASI APLIKASI E-COMMERCE BERBASIS WEB DI TOKO ABON ROJOKOYO
}

\author{
Muhammad Isroni $^{1}$, Donna Setiawati ${ }^{2}$ Fariyono $^{3}$ \\ ${ }^{1}$ Fakultas Ilmu Komputer, Universitas Boyolali \\ Email: isronimuhammad1@gmail.com \\ ${ }^{2}$ Fakultas Ilmu Komputer, Universitas Boyolali \\ Email: donna.setiawati@uby.ac.id \\ ${ }^{3}$ Fakultas Ilmu Komputer, Universitas Boyolali \\ Email: ayah.fari@yahoo.com
}

\begin{abstract}
The title of this reseacrh is the analysis, design, and implementation of E-Commerce applications with web contents in the Abon Rojokoyo store to support marketing and promotion. With the application of E-Commerce can have a positive impact on the store, especially making it easier for consumers to shop anywhere and anytime. The method used in this study is the Waterfall method, which describes a systematic and sequential approach to software development. Starting with the analysis of the needs of the company or store, then proceeding through the stages of system design or design, coding/writing program code and finally the implementation / implementation of the program code. In making the website using the PHP (Hypertext Propocecos) programming language, the Apche server and the Mysql database that have been provided in the Xamp software. For the results achieved is an E-commerce web to support marketing and promotion systems and facilitate consumers in purchasing products.
\end{abstract}

Keywords: Abon Rojokoyo Store, Waterfall, E-Commerce, PHP, MySql.

\section{Pendahuluan}

Menurut [1], E-Commerce merupakan sebuah sistem jual beli yang bersifat online, dimana seorang pembeli tidak perlu datang ke toko untuk membeli suatu barang. $E$ Commerce juga bisa dikatakan alat untuk memenejemen dan meningkatkan kecepatan layanan kepada konsumen perusahaan secara online. Saat ini E-Commerce merupakan salah satu alternatif pilihan untuk sebuah toko yang bergerak di bidang Usaha Mikro Kecil \& Menengah (UMKM) sebagai media informasi yang memudahkan adanya interaksi antara penjual dan pembeli tanpa dibatasi ruang dan waktu.

UMKM toko Abon Rojokoyo adalah perusahaan yang bergerak di bidang cemilan seperti Abon sapi, Abon ayam serta aneka cemilan lainya. Selama ini kegiatan pemasaran produk menggunakan banner, brosur, hingga online seperti facebook, instagram, dan whatsapp. Hal ini tidak menjadi masalah apabila tidak terjadi perubahan data mengenai produk yang ditawarkan, tetapi apabila terjadi perubahan data, maka perusahaan harus mempromosikan ulang melalui akun media sosial tersebut.

Sasaran konsumen yang membeli tidak hanya dari Boyolali saja. Perusahaan ini ingin memudahkan pembeli yang berasal dari luar Kota dan Provinsi. Namun terdapat kendala dalam memperluas promosi dan pembayaran yang belum via transfer. Bagi calon konsumen yang akan membeli produk jadi enggan untuk membeli produknya. Secara tidak langsung hal ini menjadi kerugian tersendiri bagi perusahaan Abon Rojokoyo karena kehilangan calon pembelinya.

Sebagai alternatif pihak perusahaan perlu untuk melakukan penambahan terhadap sistem yang mendukung pemasaran produk sebelumnya. Perusahaan membutuhkan suatu sarana pemasaran dan promosi, hingga transaksi yang aman, serta mampu mengelola data produk dan layanan dengan baik. 


\section{KAJIAN LITERATUR}

\subsection{Pengertian UMKM}

Berdasarkan [2], UMKM (Usaha Mikro Kecil dan Menengah) adalah usaha produktif milik orang perorangan atau badan usaha yang memenuhi kriteria sebagaimana diatur dalam Undang-Undang ini.

a. Usaha mikro merupakan kegiatan usaha yang dapat memperluas lapangan pekerjaan serta memberikan pelayanan ekonomi secara luas kepada masyarakat dan dapat berperan dalam proses pemerataan dan peningkatan pendapatan masyarakat, mendorong pertumbuhan ekonomi, serta berperan mewujudkan stabilitas nasional. Selain itu, usaha mikro adalah salah satu pilar utama ekonomi nasional yang medapatkan kesempatan utama, dukungan, perlindungan serta pengembangan yang secara luas ebagai wujud pihak yang tegas kepada kelompok usaha ekonomi rakyat, tanpa harus mengabaikan peranan usaha besar dan badan usaha milik pemerintah.

b. Usaha Kecil adalah usaha ekonomi produktif yang berdiri sendiri, yang dilakukan oleh orang perorangan atau badan usaha yang bukan merupakan anak perusahaan atau bukan cabang perusahaan yang dimiliki, dikuasai, atau menjadi bagian baik langsung maupun tidak langsung dari usaha menengah atau usaha besar yang memenuhi kriteria Usaha Kecil sebagaimana dimaksud dalam UndangUndang ini.

c. Usaha Menengah adalah usaha ekonomi produktif yang berdiri sendiri, yang dilakukan oleh orang perseorangan atau badan usaha yang bukan merupakan anak perusahaan atau cabang perusahaan yang dimiliki, dikuasai, atau menjadi bagian baik langsung maupun tidak langsung dengan Usaha Kecil atau usaha besar dengan jumlah kekayaan bersih atau hasil penjualan tahunan sebagaimana diatur dalam Undang-Undang ini.

\subsection{Pengertian E-Commerce}

E-Commerce merupakan suatu proses yang dilakukan konsumen dalam membeli dan menjual berbagai produk secara elektronik dari perusahaan ke perusahaan lain dengan menggunakan komputer sebagai perantara transaksi bisnis yang dilakukan. Meninjau pengertian $E$ Commerce dari empat perspektif, yaitu :

a. Perspektif komunikasi, E-Commerce ialah sebuah proses pengiriman barang, layanan, informasi, atau pembayaran melalui komputer ataupun peralatan elektronik lainnya.

b. Perspektif proses bisnis, E-Commerce merupakan sebuah aplikasi dari suatu teknologi menuju otomatisasi dari transaksi bisnis dan aliran kerja.

c. Perspektif layanan, E-Commerce ialah suatu alat yang memenuhi keinginan perusahaan, manajemen, dan konsumen untuk mengurangi biaya layanan (service cost) ketika meningkatkan kualitas barang dan meningkatkan kecepatan layanan pengiriman.

d. Perspektif online, E-Commerce menyediakan kemampuan untuk membeli dan menjual produk atau barang serta informasi melalui layanan internet maupun sarana online yang lainnya [3].

\subsection{Manfaat E-Commerce Dalam Dunia Bisnis}

E-Commerce mengandung banyak manfaat dalam dunia bisnis selain mempermudah proses jual beli, dengan menggunakan E-Commerce dapat mengurangi biaya barang dan jasa, juga bisa meningkatkan kepuasan pembeli atau konsumen dengan kecepatan untuk memperoleh barang yang dibutuhkan sesuai dengan budget dan harganya.

Istilah Ordercycle yaitu sebuah bisnis yang awalnya memakan waktu 30 hari, bisa dipercepat waktunya hingga bisa 5 hari saja. Proses yang cepat tentu akan menigkatkan pendapatan. Dengan menggunakan $E$ Commerce dapat memungkinkan untuk bertransaksi dengan cepat, mudah dan biaya yang murah tanpa melalui proses yang rumit, di mana pembeli cukup mengakses internet ke website suatu perusahaan yang mengiklankan produknya di internet. kemudian pembeli cukup mempelajari ketentuan ketentuan yang diisyaratkan (term of condition) dari pihak penjual. Tidak menghabiskan banyak waktu dan sangat kondusif. 


\subsection{Dampak Positif Dan Negatif}

1. Dampak positif dari E-Commerce antara lain:

a. Aliran pendapatan (Revenue Stream) baru yang mungkin jauh lebih menjanjikan yang tidak ditemui di sistem jual beli di pasar tradisional.

b. Mampu meningkatkan market exposure.

c. Mampu mengurangi biaya operasional (operating cost).

d. Dapat memperluas jangkauan (global reach).

e. Mampu meningkatkan customer loyality.

f. Mampu meningkatkan supplier management.

g. Dapat mempersingkat waktu produksi.

h. Meningkatkan value chain (mata rantai pendapatan).

2. Dampak negatif dari E-Commerce antara lain:

a. Akan kehilangan dari segi finansial secara langsung karena adanya kecurangan. Seorang penipu mentransfer uang dari rekening satu ke rekening lainnya atau dia telah mengganti semua data finansial yang ada.

b. Adanya pencurian informasi yang sangat rahasia dan berharga. Gangguan yang muncul bisa membongkar semua informasi rahasia itu pada pihak yang tidak berhak dan mengakibatkan kerugian besar bagi korban.

c. Kehilangan kesempatan bisnis atau kerugian pelanggan karena gangguan pelayanan. Seperti kesalahan yang bersifat non-teknis (aliran listrik tibatiba padam).

d. Adanya pengaksesan ke sumber pihak yang tidak berhak. Seperti seorang hacker yang membobol sistem perbankan. Kemudian memindahkan sejumlah rekening milik orang lain ke rekeningnya sendiri.

e. Dapat kehilangan sebuah kepercayaan dari para konsumen. Karena faktorfaktor seperti adanya usaha sengaja yang dilakukan oleh pihak luar yang berusaha menjatuhkan reputasi perusahaan tersebut.

f. Terjadinya kerugian yang tidak terduga-duga, karena adanya gangguan yang dilakukan dengan sengaja, ketidakjujuran, kesalahan dari faktor manusia ataupun kesalahan dari sistem elektronik [4].

\subsection{Komponen $\boldsymbol{E}$-Commerce}

E-Commerce memiliki beberapa komponen standar yang dimiliki dan tidakdimiliki transaksi bisnis yang dilakukan secara offline, yaitu :

1. Produk: Banyak jenis produk yang bisa dijual melalui internet seperti komputer, buku, musik, pakaian, mainan, dan lainlain.

2. Cara menerima pesanan: email, telpon, sms dan lain-lain.

3. Cara pembayaran: Cash, cek, bankdraft, kartu kredit, internet payment (misalnya paypal).

4. Metode pengiriman: pengiriman bisa dilakukan melalui paket,salesman, atau didownload jika produk yang dijual memungkinkan untuk itu (misalnya software).

5. Customer service: email, formulir online, FAQ, telpon, dan chatting.

\subsection{Metode Transaksi E-Commerce}

Menurut [5], dalam transaksi yang menggunakan E-Commerce terdapat 3 metode pembayaran yang dapat digunakan:

\section{Online Procesing Credit Cart}

Metode ini digunakan untuk produk yang bersifat retail dimana mencakup pasar yang sangat luas yaitu seluruh dunia. Pembayaran dilakukan secara langsung atau saat itu juga.

2. Money Transfer

Pembayaran dalam metode ini lebih aman namun membutuhkan biaya fee bagi pihak penyedia jasa money transfer untuk mengirim sejumlah uang ke Negara lain.

3. Cash on Delivery

Pembayaran dengan bayar di tempat ini hanya bisa dilakukan jika konsumen langsung data ke toko tempat produsen menjual produknya atau berada dalam satu wilayah yang sama dengan penyedia jasa.

\subsection{Sistem Pendukung Penerapan $E$ - Commerce}

Menurut [6]. :

1. Web (World Wide Web) 
World Wide Web ("WWW', atau singkatannya"Web") adalah suatu ruang informasi yang dipakai oleh pengenal global yang disebut Uniform Resource Identifier (URI) untuk mengidentifikasi sumber-sumber daya yang berguna. Sedangkan web based adalah suatu aplikasi yang dapat berjalan sesuai aturan web, diantaranya berjalan hanya pada web browser dan dapat diakses oleh siapa saja asalkan terhubung dengan jaringan. Hipertext dilihat dengan sebuah program bernama penjelajah web yang mengambil informasi (disebut "dokumen" atau "halaman web") dari server web dan menampilkannya, biasanya disebuah tampilan komputer. Disetiap halaman dapat pindah ke dokumen lain atau bahkan mengirim informasi kembali kepada peladen untuk berinteraksi dengannya. Ini disebut "surfing" atau "berselancar" dalam bahasa Indonesia. Halaman web biasanya diatur dalam koleksi material yang berkaitan yang disebut "situs web.

2. MySQL

MySQL merupakan suatu bahasa yang digunakan untuk mengakses database relasional". Bahasa ini mendukung perintah untuk membuat database, menciptakan tabel, menambah data, mengubah data, menghapus data dan mengambil data yang berada dalam database. SQL juga menyediakan perintah untuk mengatur akses database sehingga keamanan data bisa terjamin. Artinya, bisa diatur agar pemakai tertentu hanya bisa mengakses data tertentu.

3. HTML

Hypertext Markup Language (HTML) yaitu salah satu bahasa scripting yang dapat menghasilkan halaman website sehingga halaman tersebut dapat diakses pada setiap komputer pengakses (client).

4. Hipertext Preprocessor (PHP)

PHP adalah bahasa pemrograman yang ditujukan untuk pembuatan aplikasi web. PHP memungkinkan pembuatan aplikasi web yang dinamis, dalam arti dapat membuat halaman web yang dikendalikan oleh data. Dengan demikian, perubahan data akan membuat halaman web ikut berubah tanpa harus mengubah kode yang menyusun halaman web.

5. Xampp
XAMPP adalah sebuah software yang berfungsi untuk menjalankan website berbasis PHP dan menggunakan pengolah data MySQL dikomputer local". XAMPP berperan sebagai server web pada komputer anda. XAMPP juga dapat disebut sebuah CPanel server virtual, yang dapat membantu anda melakukan preview sehingga dapat memodifikasi website tanpa harus online atau terakses dengan internet.

\subsection{Metode Waterfall}

Menurut [7], Metode Waterfall adalah sebuah metode pengembangan software yang bersifat sekuensial. Inti dari metode waterfall adalah pengerjaan dari suatu system dilakukan secara berurutan atau secara linear. Jadi jika langkah satu belum dikerjakan maka tidak akan bisa melakukan pengerjaan langkah 2, 3 dan seterusnya. Secara otomatis tahapan ke-3 akan bisa dilakukan jika tahap ke-1 dan ke-2 sudah dilakukan. Secara garis besar Berikut penjelasan mengenai fase fase dalam waterfall

\section{Analisa kebutuhan (Requirement Analysis)}

Langkah ini merupakan analisa terhadap kebutuhan sistem. Pengumpulan data dalam tahap ini bisa malakukan sebuah penelitian, wawancara atau study literatur. Seorang system analis akan menggali informasi sebanyak-banyaknya dari user sehingga akan tercipta sebuah system komputer yang bisa melakukan tugas-tugas yang diinginkan oleh user tersebut. Tahapan ini akan menghasilkan dokumen user requirement atau bisa dikatakan sebagai data yang berhubungan dengan keinginan user dalam pembuatan sistem. Dokumen inilah yang akan menjadi acuan system analis untuk menterjemahkan kedalam bahasa pemprogram.

\section{Design/perancangan system}

Proses desain akan menerjemahkan syarat kebutuhan kesebuah perancangan perangkat lunak yang dapat diperkirakan sebelum dibuat coding. Proses ini berfokus pada struktur data, arsitektur perangkat lunak, representasi interface, dan detail (algoritma) prosedural. Tahapan ini akan menghasilkan dokumen yang disebut software requirment. Dokumen inilah yang akan digunakan programmer untuk 
melakukan aktivitas pembuatan sistemnya.

3. Coding / penulisan kode program

Coding merupakan penerjemahan design dalam bahasa yang bisa dikenali oleh komputer. Dilakukan oleh programmer yang akan meterjemahkan transaksi yang diminta oleh user. Tahapan inilah yang merupakan tahapan secara nyata dalam mengerjakan suatu sistem. Dalam artian penggunaan computer akan dimaksimalkan dalam tahapan ini. Setelah pengkodean selesai maka akan dilakukan testing terhadap sistem yang telah dibuat tadi. Tujuan testing adalah menemukan kesalahan-kesalahan terhadap system tersebut dan kemudian bisa diperbaiki.

4. Penerapan / pengujian program (Integration \& Testing)

Tahapan ini bisa dikatakan final dalam pembuatan sebuah sistem.Setelah melakukan analisa, design dan pengkodean maka sistem yang sudah jadi akan digunakan oleh user.

\subsection{Penelitian Terdahulu}

[8] Melakukan penelitian tentang perkembangan teknologi informasi yang mempengaruhi gaya hidup manusia dalam melakukan transaksi jual beli, dengan memanfaatkan media E-Commerce maka transaksi jual beli tidak harus penjual dan pembeli bertemu secara langsung. Toko Aska menginginkan dalam mengembangkan usahanya memiliki media jual beli tanpa kendala waktu dan jarak. Tujuan dari penelitian ini menghasilkan website E-commerce sebagai media transaksi jual beli online yang terintegrasi dengan sistem informasi transaksi berbasis SMS Gateway, metode pembangunan sistem menggunakan metode waterfall.

[9] Melakukan penelitian tentang sistem informasi penjualan pupuk berbasis E-commerce. Kebutuhan Pupuk dalam bidang pertanian sangatlah penting. Untuk membantu kesuburan tanah dan tanaman sehingga mendapatkan hasil yang bagus. PT. Pertani (Persero) merupakan perusahaan yang bergerak dibidang pendistribsian pupuk cabang Riau. Di PT.Pertani (Pesero) cabang Riau ini, rangkaian proses penjadwalan pengirman pupuk yang dimulai dari pembuatan booking order, penjadwalan sampai proses pengiriman semuanya masih dilakukan dengan manual. Tujuan penelitian ini yaitu akan merancang sebuah Sistem Informasi Penjualan Pupuk di PT. Pertani (Persero) cabang Riau yang akan mengurangi kesalahan pendokumentasian. Langkah untuk merancangnya adalah melalui tahapan-tahapan sebagai berikut: 1) Studi Literatur. 2) Pengumpulan data dan wawancara. 3) Menganalisa data yang telah didapat untuk mendapatkan kebutuhan pengguna. 4) Mendesain sistem menggunakan metode OOAD (Object Oriented and Design).

[10] Melakukan penelitian tentang penerapan metode K-Means Untuk Clustering produk Online Shop. Penelitian ini bertujuan untuk mengelompokkan produk yang dijual pada online shop Ragam Jogja menjadi beberapa cluster untuk mengetahui produk mana yang paling diminati sehingga jumlah stok harus banyak, produk diminati untuk jumlah stok sedang dan produk kurang diminati untuk jumlah stok sedikit. Metode yang digunakan pada penelitian ini adalah metode K-Means yang merupakan salah satu metode terbaik dan paling popular dalam algoritma clustering dimana KMeans mencari partisi yang optimal dari data dengan meminimalkan kriteria jumlah kesalahan kuadrat dengan prosedur iterasi yang optimal. Variabel yang digunakan adalah kode produk, jumlah transaksi, volume penjualan dan rata-rata penjualan. Penelitian juga didukung dengan software Rapidminer untuk pengolahan data dengan metode K-Means. Hasil akhir dari penelitian adalah berupa suatu program aplikasi yang dapat mengelompokkan produk menjadi kategori jumlah stok banyak, sedang dan sedikit berdasarkan transaksi penjualan.

\subsection{Penelitian Sekarang}

Penelitian sekarang dilakukan pada toko Abon Rojokoyo. Melihat pesatnya kemajuan teknologi informasi dalam hal ini pemanfaatan internet yang juga telah marak digunakan para pelaku industri untuk menambah pangsa pasar. Untuk itu tujuan dari penelitian ini adalah menganalisa dan merancang dan implementasi sebuah aplikasi web E-Commerce dengan pemrograman php 
dan mysql. Dengan adanya website nanti dapat mengenalkan toko Abon Rojokoyo kepada masyarakat luas. Dengan adanya website pihak toko dapat mempromosikan, mengenalkan produknya, dan melakukan penjualan atau pemasaran produk dengan lebih luas di internet.

\section{METODOLOGI PENELITIAN}

Penelitian ini mengambil objek pada UMKM toko Abon Rojokoyo yang beralamat di Plosokerep, Winong, Boyolali. Bahan yang digunakan antara lain: Data penjualan berupa daftar produk yang dihasilkan, harga produk, identitas pemilik usaha, Dokumentasi hasil produk.

\subsection{Analisis Kebutuhan \& Fungsional Sistem Toko}

Analisis kebutuhan adalah mempersiapkan output apa saja yang akan diterapkan di web toko Abon Rojokoyo. Metode yang digunakan dalam analisis kebutuhan ini yaitu wawancara, pengamatan secara langsung, dan literatur pustaka. Untuk pengamatan secara langsung dan literatur pustaka dilakukan secara langsung di toko Abon Rojokoyo, yang beralamat di Plosokerep, Winong, Kab. Boyolali. Berdasarkan hasil wawancara dengan pemilik toko Abon Rojokoyo Ibu Hj. Harto Sumardjo yang dilaksanakan pada Hari Minggu, Tanggal 01 April 2018, maka dapat disimpulkan bahwa permasalahan yang dihadapi toko Abon Rojokoyo adalah sistem informasi terkait produk serta sistem promosi untuk menjangkau konsumen yang lebih luas lagi.

Untuk kebutuhan fungsional dari sistem yang akan dibuat yaitu sebagai berikut:

a. Sistem harus ada menu yang menampilkan informasi tentang toko Abon Rojokoyo.

b. Sistem harus menyediakan menu yang dapat menampung komentar atau kritik saran dari konsumen.

c. Sistem harus dapat memberikan menu informasi produk toko Abon Rojokoyo kepada konsumen.

d. Sistem harus bisa menampilkan detail produk. e. Sistem harus dapat menangani proses promosi, pemesanan produk, dan transaksi.

\subsection{Desain/Perancangan Sistem}

Perancangan sistem merupakan gambaran spesifikasi sitem yang akan dibuat sesuai dengan analisa sistem, seperti desain database, diagram admin, user, relasi antar database, dan perancangan desain web. Berikut hasil desain dan perancanganya :

\section{Relasi tabel}

Relasi tabel merupakan hubungan antara tabel yang mempresentasikan hubungan antar object di dunia nyata, dan berfungsi untuk mengatur operasi suatu database.

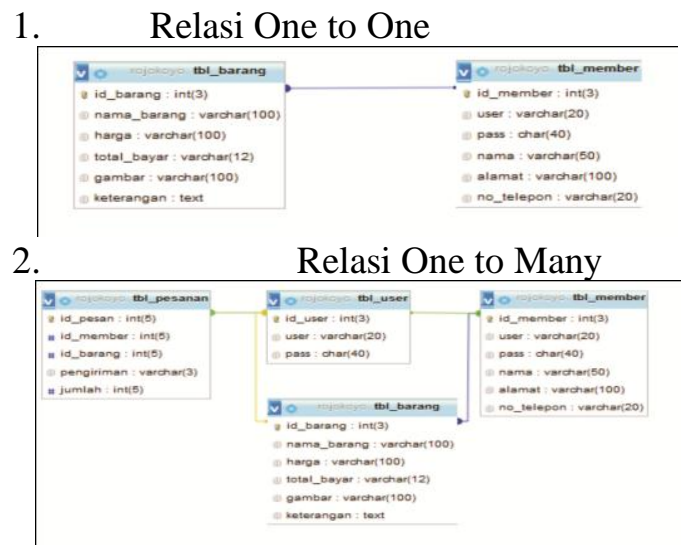

\section{Data Integrity}

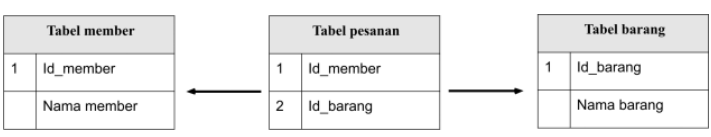

Data Integrity merupakan salah satu fungsi dari Database management System (DBMS), yakni memastikan baik data dalam basis data maupun mengubah data selalu memenuhi aturan. Data Integrity berkaitan dengan kebenarandan konsistensi dari data yang disimpan, dimana berkaitan dengan constraint yang merupakan aturan dalam basis data yang tidak dapat dilanggar. (Connoly, 2010:103).

\section{Diagram admin}




Keterangan :

a. Admin dapat menambah, edit, serta menghapus barang

b. Admin dapat melihat,serta menghapus pesanan sesuai data yang sudah selesai di pesan oleh pelanggan.

c. Admin dapat melihat member yang sudah mendaftar serta dapat menghapus member.

d. Admin dapat melihat pesan kritik saran dari pelanggan.

e. Admin dapat memperbarui data admin.

\section{Diagram member}

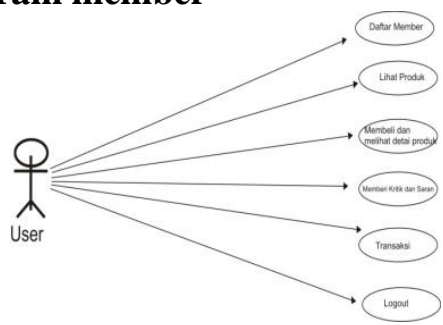

Keterangan :

a. Member dapat login untuk melihat membeli produk.

b. Member dapat memberi pesan kritik dan saran.

\subsection{Coding/penulisan kode program}

Merupakan proses pengetikan dan menguji kode program dengan bahasa pemrograman PHP melalui softwere $\mathrm{C}++$. Berikut tampilan dari halaman $\mathrm{C}++$ :

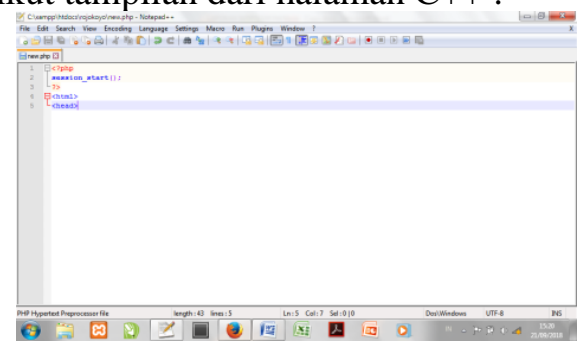

Setelah melakukan pengetikan kode pemrograman di $\mathrm{C}++$ file disimpan dengan format php didalam folder di Htdocs. Didalam pembuatan laporan skripsi ini folder yang penulis buat adalah rojokoyo yaitu di direktory: C/Xampp/htdocs/rojokoyo. Untuk dapat memanggil atau menguji kode program harus menjalankan server Apache serta database MySql di Control panel yang sudah disediakan di softwere Xampp. Berikut gambar tampilan Control panel Xampp:



Setelah tahap pembuatan folder di htdocs dan menjalankan server apache, Mysql langkah selanjutnya adalah menguji kode progam atau memanggil kode tersebut melalui web browser dengan Url: localhost/rojokoyo.

\subsection{Penerapan/Implementasi}

Implementasi merupakan tahap pelaksanaan atau penerapan sistem dari perancangan yang sudah disususun secara matang. implementasi sistem dilakukan dengan mengacu pada perancangan sistem dan disesuaikan dengan kebutuhan. Pengembangan sistem dilakukan dengan pengodingan skrip $\mathrm{PHP}$ di $\mathrm{C}++$, pengujian hasil coding dengan web browser. Website ECommerce ini dirancang sebagai media pendukung penjualan secara online bagi toko Abon Rojokoyo yang selama ini melakukan pemasaran dan promosi hanya menggunakan lisan ke lisan dan media sosial yang ada. Harapanya dengan menggunakan website ini dapat menambah sistem yang sudah berjalan.

\section{HASIL DAN PEMBAHASAN}

\section{A. Penjelasan Aplikasi Web}

Sistem ini berjalan menggunakan web browser dengan mengaktifkan server Apache dan database mySql di softwere Xampp. Untuk memanggil sistem yaitu dengan URL; http://localhost/rojokoyo/. Berikut tampilantampilan yang ada dalam website :

\section{Halaman beranda/utama}

Merupakan halaman muka dari website toko Abon Rojokoyo yang berisi sub menu pada website. Adapun gambar dan isi halaman sebagai berikut: 


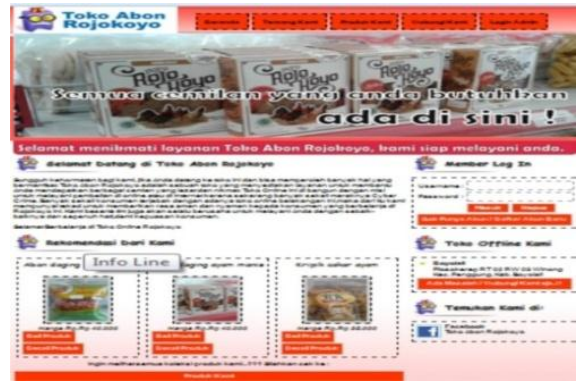

a. Ucapan selamat datang

Ucapan selamat datang merupakan bagian isi dari halaman beranda, dimana setiap kali pengunjung masuk akan melihat ucapan selamat datang tersebut. Berikut gambar ucapan selamat datang :

Selamat Datang di Toko Abon Rojokoyo

Sungguh kehormatan bagi kami, jika Anda datang ke toko ini dan bisa memperoleh banyak hal yang bermantaat Toko Abon Rojokoyo adalah sebuah toko yang menyediakan layanan untuk membantu Anda mencapaikan berbaga cemlan yang lezat can nikmat Toko Onine in la bangun dengan misi untuk melayan pembelian di onine alau di internet karena sekarang banyak sekali maraknya Cyber Crime. Banyak sekali memberkan rasa aman dan nyaman kepacla konsumen yang berbelania di Rojikoyo in Kamian beserta tim iuga akan selalu berusaha untuk melayani Anda dengan sebaik-baiknya dan sepenuh hati, demi kepuasan konsumen.

Selamat Berbelanja di Toko Onine Rojokoyo

\section{b. Log-in member}

Login member merupakan menu yang disajikan bagi pengunjung yang akan melakukan pembelian, setiap pengunjung yang ingin membeli produk harus melakukan pendaftaran member. Berikut gambar Log-in member :

\section{Member Log In}

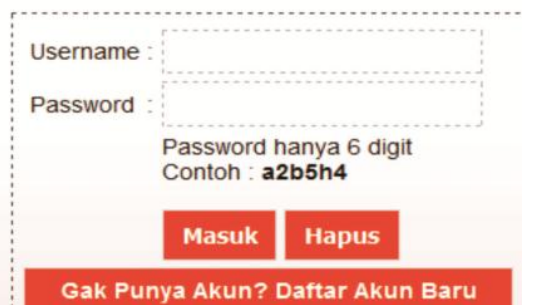

Gak Punya Akun? Daftar Akun Baru

\section{c. Registrasi member}

Registrasi member merupakan halaman yang disajikan untuk pengunjung yang hendak melakukan pembelian namum belum mempunyai username dan password, oleh karena itu pengunjung harus melakukan registrasi member terlebih dahulu. Berikut gambar registrasi member :
Registrasi Member

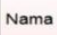

Username

Password Alamat Sesuai

Nomor Telepon

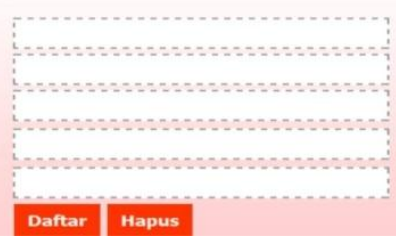

d. Rekomendasi produk

Rekomendasi produk merupakan bagian dari halaman beranda, dimana halaman utama yang dibuka pengunjung terdapat produk yang direkomendasikan untuk pengunjung. Berikut gambar rekomendasi produk :

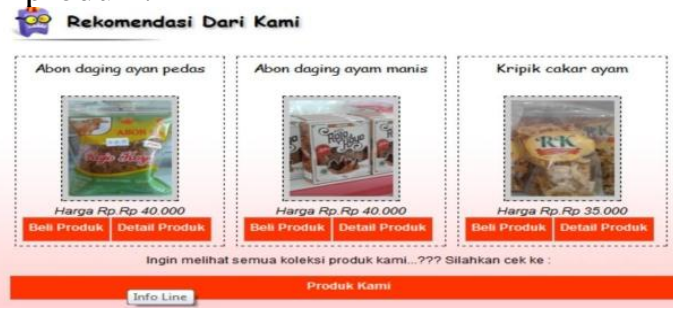

e. Toko ofline

Toko ofline merupakan bagian dari tampilan menu beranda, dengan tujuan untuk memberikan infromasi kepada pengunjung mengenai toko ofline atau tempat penjualan yang dapat dikunjungi. Berikut gambar dari tampilan toko ofline :

\section{Toko Offline Kami}

\section{Boyolali}

Plosokerep RT 02 RW 03 Winong Kec. Penggung, Kab. Boyolali

Ada Masalah? Hubungi Kami aja...!

\section{Halaman tentang kami}

Halaman tentang kami merupakan halaman sub menu kedua setelah beranda yang disediakan bagi pengunjung, yang berisikan tentang sejarah, jumlah pegawai, dan visi misi yang telah disiapkan oleh administrator. Berikut gambar tentang kami : 


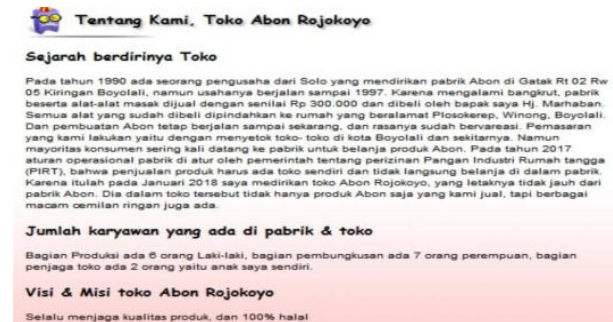

\section{Halaman produk}

Halaman produk merupakan halaman yang sub ketiga setelah halaman tentang kami, disajikan untuk pengujung yang berisikan tentang pembelian produk dan detail produk. Berikut gambar halaman produk dan isi dari halaman tersebut :

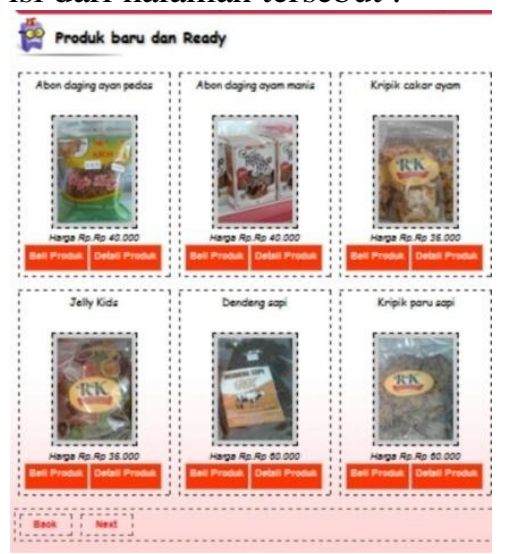

a. Beli produk

Merupakan tools yang berada di bawah gambar produk yang disediakan untuk pengunjung apabila hendak melakukan pembelian dengan mengeklik tools tersebut, nantinya akan dilanjutkan ke jumlah pembelian dan pengiriman. Berikut gambar dari tools beli produk:

Pesan Abon daging ayam manis

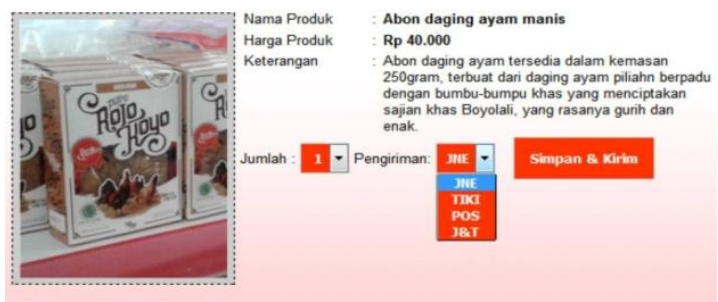

\section{b. Detail produk}

Merupakan tools yang berada dibawah gambar prdouk yang disediakan untuk prengujung yang ingin melihat detail produk yang akan dibeli. Berikut gambar dari detai produk:

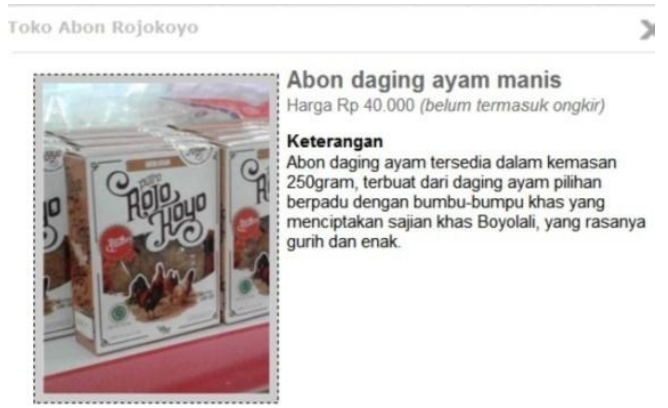

\section{Halaman hubungi}

Halaman hubungi merupakan halaman yang disediakan di sub menu keempat bagian atas setelah halaman produk, dihalaman ini berisikan tentang kritik dan saran dari pengunjung. Berikut gambar isi dari halaman hubungi :

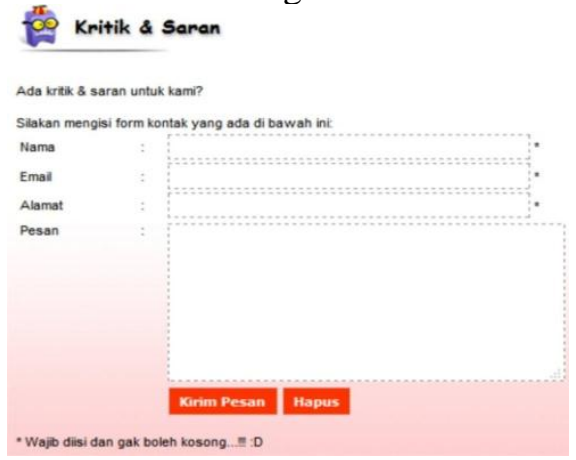

\section{Log-in admin}

Log-in admin merupakan halaman sub menu kelima di atas setelah halaman hubungi, halaman ini merupakan tampilan halaman ketika admin akan login ke website. Berikut gambar login admin :

Username Admin

Password Admin

\section{Masuk Hapus}

\section{Beranda admin}

Beranda admin merupakan halaman utama setelah administrator login ke website, halaman ini berisikan tentang ucapan selamat datang, tugas administrator, dan lain-lain. Berikut gambar beranda admin :

Selamat Datang di Halaman Admin Abon Rojokoyo

Selamat Datang di Halaman Admin Abon Rojokoyo

rugas Administrator meliputi melihat pesanan produk, melihat member, mengupdate barang. me Semua isi website terkatt pengetikan, konten, gambar dan sebagainya ditanggung jawabi oleh A Ziri Administrator yang baik :

1. Telit Telit
Memiliki kemampuan berhitung dengan baik
Memilik kemampuan menggunakan apilikass administratif secara ofline maupun online mampu melakukan pendekatan metodis dan menyeluruh untuk kerja
matum 5. Mampu bekeria dengan tim
1. Memiliki Inisiati 


\section{Produk admin}

Produk admin merupakan sub menu kedua setelah beranda admin, halaman ini berisikan produk-produk yang di isi oleh administrator serta administrator dapat merubah, menghapus dan menambah produk yang akan di pasang di halaman produk. Berikut gambar isi menu prosuk produk admin :

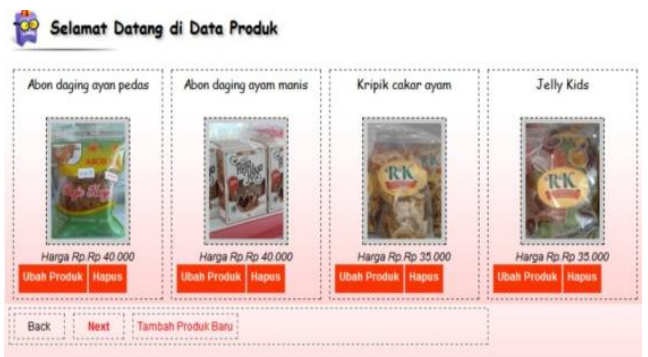

a. Ubah produk

Merupakan halaman yang menampilkan jika administrator hendak melakukan perubahan pada produk, seperti nama produk, harga, dan gambar. Berikut gambar ubah produk :

\begin{tabular}{l|l|}
\hline $\begin{array}{l}\text { Toko Abon Rojokoyo } \\
\text { Barang } \\
\text { Harga } \\
\text { Barang } \\
\text { Keterangan }\end{array}$ & Abon daging ayam manis \\
\hline & $\begin{array}{l}\text { Abon daging ayam tersedia dalam kemasan } \\
\text { 250gram, terbuat dari daging ayam pilihan } \\
\text { berpadu dengan bumbu-bumpu khas yang } \\
\text { menciptakan sajian khas Boyolali, yang rasanya } \\
\text { gurih dan enak. }\end{array}$ \\
\hline Gambar & Telusuri... \\
\hline & Tidak ada berkas dipilih. \\
\hline & Update \\
\hline
\end{tabular}

b. Hapus produk

Hapus produk merupakan tools yang berada dibawah gambar produk admin, apabila admin hendak menghapus produk dengan mengeklik tools tersebut. Berikut gambar tools hapus produk :

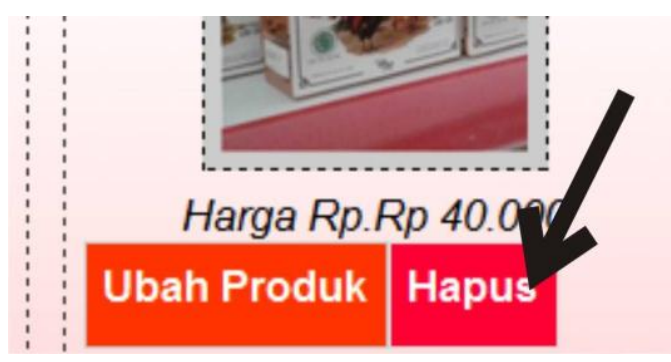

c. Tambah produk

Tambah produk merupakan tools yang berada di bagian bawah setelah gambar produk admin, tools tersebut digunakan apabila administrator hendak melakukan penambahan produk. Berikut gambar tambah produk:

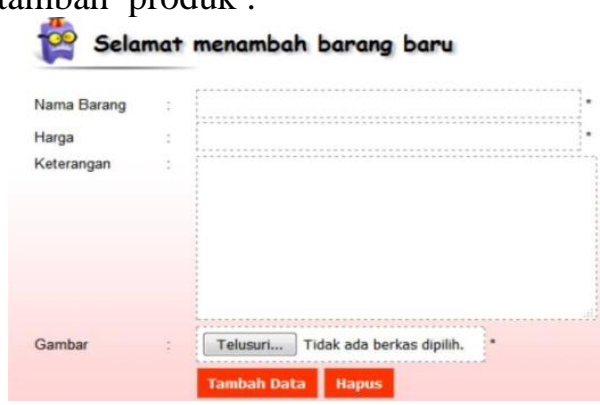

\section{Pesanan produk}

Pesanan produk merupakan halaman yang berisi produk-produk yang dipesan oleh pengunjung yaitu terkait nomor pesanan, nama pemesan, nama barang, jumlah pesanan, pengiriman, dan tindakan admin yaitu selesai dan hapus. Berikut gambar dari pesanan produk :



\section{Gambar 4.18 Pesanan produk}

\section{Member}

Halaman member merupakan halaman yang berisikan pengunjung yang sudah mendaftar sebagai member, yaitu terkait nomor, nama member, username, alamat, no telepon, serta tindakan admin yaitu hapus member. Berikut gambar halaman member :

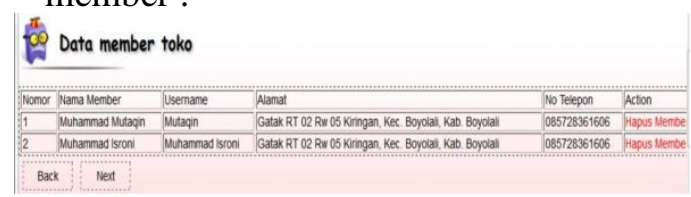

\section{Hubungi}

Hubungi merupakan halaman yang berisi pesan atau kritik dan saran dari pengunjung kepada administrator, terkait dengan nama, e-mail, alamat, isi pesan atau kritik \& saran, serta tindakan admin berupa hapus pesan. Berikut gambar dari halaman hubungi : 


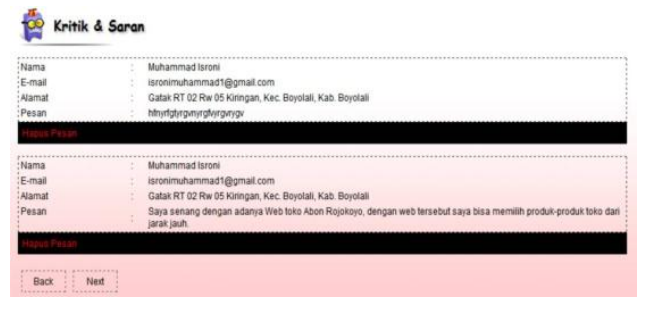

11. Password admin

Merupakan halaman administrator yang hendak melakukan perubahan data admin, terkait username, dan password. Berikut gambar tampilan password admin :

Ganti password Admin?

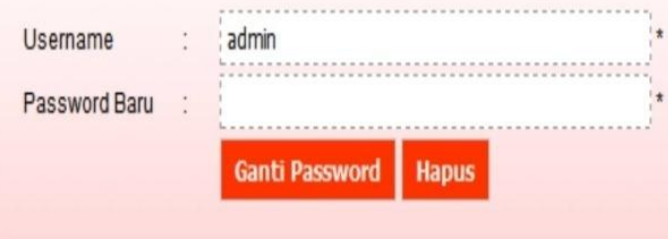

12. Log-out admin

Log-out admin merupakan tools yang ada di sub menu bagian atas yang berfungsi untuk keluar dari halaman admin. Berikut gambar log-out admin :

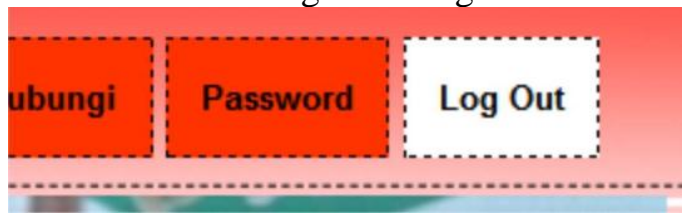

\section{PENUTUP}

Berdasarkan hasil penelitian di toko Abon Rojokoyo dibangun, maka dapat di ambil kesimpulan sebagai berikut :

a. Ditemukanya analisis sistem yang sudah berjalan dan penambahan sistem baru untuk toko.

b. Perancangan sistem aplikasi ECommerce berbasis web dapat di implementasikan di toko Abon Rojokoyo.

c. Dengan adanya website ini maka penjualan di toko dapat memperluas pemasaran dan konsumen menjadi lebih mudah mendapatkan informasi tentang produk tanpa harus datang ke toko Abon Rojokoyo.

d. Dengan adanya sistem penjualan online (E-Commerce) maka dapat memudahkan transaksi dari jarak jauh. Dimana pelanggan di luar Boyolali tetap dapat melakukan transakasi tanpa harus datang ke toko Abon Rojokoyo.

Ada beberapa saran yang dapat menjadi bahan pertimbangan dalam upaya meningkatkan pemasaran dan promosi serta untuk meningkatkan kualitas sistem dimasa yang akan datang diantaranya yaitu :

a. Perlu adanya pengembangan pada desain tampilan atau template yang lebih menarik sehingga dapat lebih banyak memikat pelanggan.

b. Perlu adanya fasilitas lain yang mendukung fungsionalitas website, seperti diskon. Sehingga konsumen akan terus mengunjungi website dengan kata lain jika sering masuk website maka kemungkinan untuk belanjapun semakin tinggi.

\section{REFERENSI}

[1] Kristanto,. 2013. Perancangan Sistem Informasi Dan Aplikasinya, Penerbit Gaya Media Yogyakarta.

[2] Undang-undang Republik Indonesia Nomor 20 Tahun 2008, Usaha mikro kecil dan menengah.

[3] Asnawi,. 2013. Transaksi Bisnis ECommerce. Jogjakarta : Magistra Insani.

[4] Oetomo, Budi Sutedjo Dharma,. 2011. Perencanaan dan Pembangunan Sistem Informasi. Yogyakarta : Penerbit Andi.

[5] H.M.,Jogiyanto,. 2014 Analisis dan Desain Sistem Informasi: Pendekatan terstruktur teori dan praktek aplikasi bisnis. Yogyakarta: Andi.

[6] Aberg, J., and Shahmehri, N. 2012. The Role of Human Web Assistants in ECommerce: An Analysis and A Usability Study. Internet Research Electronic Networking Applications and Policy.

[7] Presmaan, Roger S. 2012. Rekayasa Perangkat Lunak -Buku Satu, Pendekatan Praktisi (Edisi 7). Yogyakarta: Andi. 
[8] Setiadi, Aris dan Ramadhian Agus Triyono. 2014. Pembangunan Website Ecommerce Dengan Sistem Informasi Transaksi Berbasis SMS Gateway pada Toko Aska. IJNS Indonesian Journal on Networking and Security Volume 3 No 1.

[9] Novita, Rice dan Novita Sari. 2015. Sistem Informasi Penjualan Pupuk Berbasis E-Commerce. Jurnal TEKNOIF Vol. 3 No. 2. Universitas Islam Negeri Sultan Syarif Kasim Riau.

[10]Muningsih, Elly dan Sri Kiswati. 2015. Penerapan Metode K-Means Untuk Clustering Produk Online Shop Dalam Penentuan Stok Barang. Jurnal Bianglala Informatika Vol 3 No 1. AMIK BSI Yogyakarta. 